International Journal of Environment, Agriculture and Biotechnology
Vol-6, Issue-6; Nov-Dec, 2021
J Journal Home Page Available: https://ijeab.com/
Journal DOI: $10.22161 /$ ijeab

Peer Reviewed

\title{
The use of Coastal Land for the Cultivation of Vegetable and Species on Small Islands in the Sub-District of Tatoareng Sangihe Regency
}

\author{
Paulus Adrian Pangemanan ${ }^{1}$, Decky Kamagi ${ }^{2}$, and Farly Tumimomor ${ }^{3}$ \\ ${ }^{1}$ Department of Agribisnis, Faculty of Agriculture, Sam Ratulangi University Manado. Indonesia \\ ${ }^{2}$ Department of Biology, Faculty of Mathematics and Natural Sciences, Manado State University. Indonesia \\ ${ }^{3}$ Department of Physics, Faculty of Mathematics and Natural Sciences, Manado State University. Indonesia \\ Email: adrian_pangemanan@unsrat.ac.id
}

Received: 21 Oct 2021; Received in revised form: 01 Dec 2021; Accepted: 08 Dec 2021; Available online: 17 Dec 2021 (C2021 The Author(s). Published by Infogain Publication. This is an open access article under the CC BY license (https://creativecommons.org/licenses/by/4.0/).

\begin{abstract}
Communities on the small island of Tatoareng sub-district, Sangihe Regency, are faced with the problem of limited land ownership for vegetable cultivation, and low access to vegetable food. Vegetables purchased by the public have gone through four to five buying and selling processes starting from the production center, resulting of expensive vegetable prices. This chain of problems continues and has not yet found a way to solve it. Our team designed hydroponic vegetable and spice (herbs) cultivation on a small island in the District of Tatoareng. The initial stages of the study are analyzing the prospects for the cultivation of vegetables and spices that are the needs of the community, analyzing their suitability with ecological conditions especially the microclimate, and analyzing the economic benefits in this case income or reduction in expenditure versus production costs. Our team has conducted research on daily changes in the microclimate of residential, plantation and forest areas, as a reference for the choice of growing vegetables and herbs (spice). Our team has also conducted research on the economic condition of the family, on livelihoods, and average monthly family income. Initial research results indicate a monthly family income range between Rp. 1.000 .000 to Rp. 2.000.000. Preliminary observations also indicate that each house has a yard measuring at least $4 \mathrm{~m} x 8 \mathrm{~m}$ wich allows for the hydroponic cultivation of vegetables and herbs. This article describes the results of a prospective economic-ecological analysis of the cultivation of vegetables and herbs for low-income families. The results of the analysis present several choices of types of vegetables and herbs, prospects for economic benefits and their compatibility with microclimate conditions. Choice of vegetables and herbs that can be cultivated, has been confirmed to the public. The categories of choice of vegetables and herbs are: first priority is: tomatoes, second priority is mustard pakcoy, third priority is chilli. The results of this preliminary study became a reference for the follow up of the research on hydroponic vegetable and spice cultivation
\end{abstract}

Keywords - Coastal Land, Cultivation, Vegetable, Small Islands

\section{INTRODUCTION}

The area of Tatoareng Subdistrict, Sangihe Regency, consists of small islands that are close to each other, which can be reached by using a motorized boat belonging to the community in $20-40$ minutes. People in this sub-district are faced with the problem of expensive vegetables and spices because they have to be bought from Tahuna. The main economic activity of the community is fishing, a small number of housewives make salted fish. Some people work as civil servants (teachers, local government employees, health/nursing personnel, TNI and Polri). This population condition indicates a high level of need for consumption of spices and vegetables. The free time that housewives have is potential to be directed to grow spices and vegetables. 
The specific purpose of this study was to analyze the land conditions (soil, microclimate, availability of ground/surface water) for the cultivation of spices and vegetables designed individually (KK) or in groups based on land ownership and community agreement. The results of interviews with the community in 2017 revealed the desires and needs of the community for vegetable and spice cultivation but were constrained by several things: land ownership, procurement of seeds, cultivation and fertilization methods, long droughts, the influence of large waves that caused damage to crops in coastal areas. This research is a solution to the problem of food shortages and community empowerment innovations (especially housewives) in utilizing their spare time to cultivate spices and vegetables both for household needs and as a livelihood.

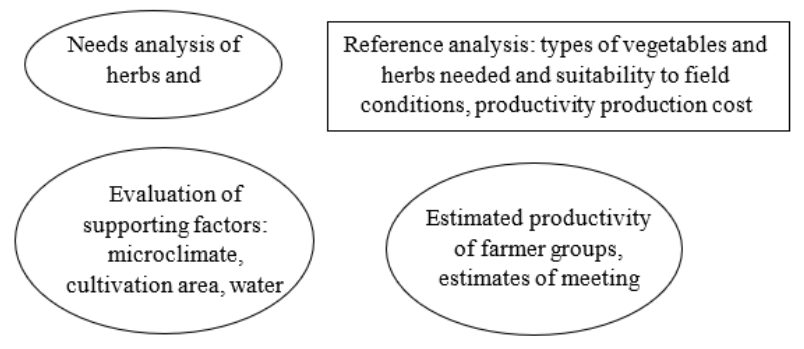

Analysis Model of Spice And Vegetable Cultivation To Fulfill Common Needs Tatoareng District is located in the southernmost position of the Sangihe District. Tatoareng District consists of nine small islands, six of which are permanent residents, while three islands are only a place for fishermen to rest. The total land area of Tatoareng District is $18.56 \mathrm{~km} 2$, with a population (in 2012): 4291 people, and a population density of $231 \mathrm{jima} / \mathrm{km} 2$ (Sangihe in figures, 2012). The settlement pattern is generally concentrated on the coast, so that the population density in the coastal area is relatively high. The area of land for agriculture is relatively small which is used for food crops (food ingredients for local people) such as cassava, sweet potatoes, vegetables, spices and fruits, and coconut plants. The main livelihood of the community is fishing (traditional), with low income due to limited marketing of catch products.

The small size of the catchment area, and the lack of vegetation cover raises the problem of water availability when there is a long dry season. Shah and Dulal (2015) [1], suggest that the strategy of the community in small islands in facing the problem of food availability, is significantly reduced due to climate change. Systemic analysis of resource management includes biophysical, socio-cultural and economic components as a whole and is a characteristic of small islands [2]. Small island agriculture requires a special approach to improve soil quality, such as organic content, aggregate stability, capacity to store groundwater, increase the ability of soil to bind carbon and minimize groundwater pollution [3].

The socio-ecological system approach should be a reference for natural resource management in small islands [4]. This system framework includes elements such as: existing cultivation practices, pressures from other sectors, such as tourism, land use habits, groundwater insecurity [3]. Leunufna and Evans (2014) [5] suggest that it is necessary to study sociological and technological aspects in the choice of utilization

land for the cultivation of spices and vegetables. To improve and strengthen the process of adaptation and integration of local knowledge with external knowledge, the community can form a forum for shared and collaborative use [6]. The process of adaptation and integration of knowledge has developed well through a participatory approach in terms of (1) planning processes [7], (2) geographic information systems [8], (3) scenario planning [9]

Based on the study of the characteristics of small islands: prone to climate change, problems of limited land related to food security, socio-economic (cost of living, local wisdom; plant cultivation habits, existing alternative economic activities, etc.), in the process of acceptance and adaptation, land use research Coastal areas for vegetable and spice cultivation are focused on:

1. Mapping of cultivation areas according to land characteristics (soil, availability of groundwater and surface runoff, microclimate), referring to the RTRW of Sangihe Regency as a development policy framework

2. Research on the physical condition of the land (microclimate, air temperature and humidity, irradiation and cycles/rainy and dry seasons).

3. Identification of community-owned cultivation patterns, strategies and mechanisms for integrating vegetable and spice cultivation technology.

4. Socio-economic analysis of the community with inputs for land use and vegetable and spice cultivation activities.

5. The principles of land management and cultivation that ensure the sustainability of land use, availability of ground water.

6. Encouraging the role of the community in research (participatory model) so that the community directly carries out the technology adoption process and the integration of local customs/wisdom. This strategy is strengthened by coordination with local governments and organizations in the community. 


\section{RESEARCH METHODS}

Flowchart of developing a spice and vegetable cultivation model to meet common needs on small islands.

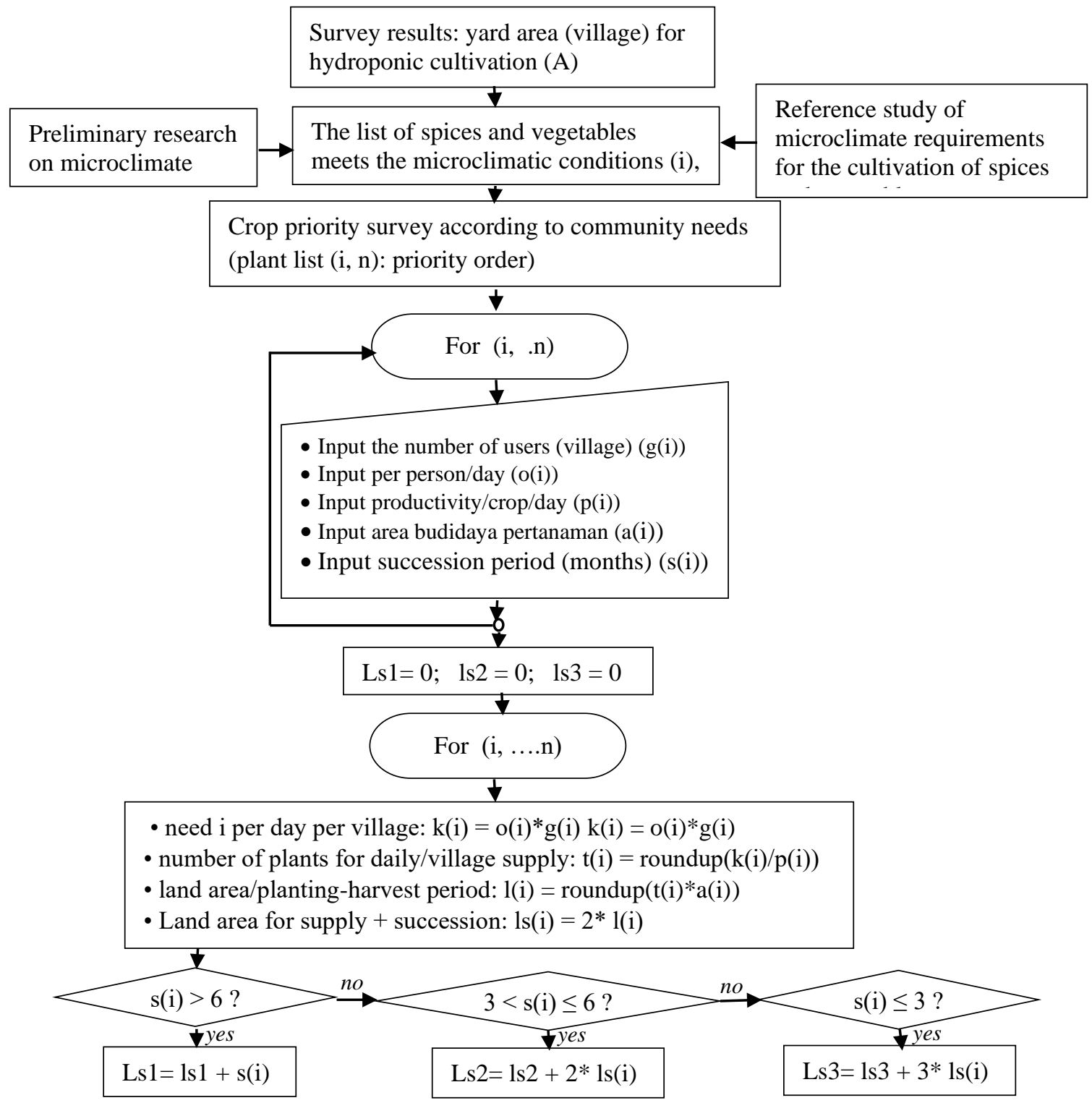

Total land area needed/year: $\mathrm{Tl}=\mathrm{Ls} 1+\mathrm{Ls} 2+\mathrm{Ls} 3$ 


\section{RESEARCH RESULT}

\section{Prospect analysis of vegetable and spice cultivation}

\begin{tabular}{|c|c|c|c|c|c|}
\hline \multirow[b]{2}{*}{$\begin{array}{l}\text { Types of } \\
\text { spices/vegetables }\end{array}$} & \multirow[b]{2}{*}{$\begin{array}{l}\text { Village needs } \\
\text { /week }(\mathrm{kg})(1)\end{array}$} & \multicolumn{2}{|c|}{ Many plants needed (2) } & \multicolumn{2}{|c|}{ Productive mass (3) } \\
\hline & & $\begin{array}{c}\text { Total } \\
\text { production } \\
\text { /day }(\mathrm{kg})\end{array}$ & $\begin{array}{c}\text { number of } \\
\text { plants }\end{array}$ & $\begin{array}{l}\text { harvest } \\
\text { time }\end{array}$ & Month \\
\hline Red onion & $5 \mathrm{~kg}$ & $0.71 \mathrm{Kg}$ & 3 & 1 & 3 \\
\hline Garlic & $3.5 \mathrm{~kg}$ & 0.5 & 2 & 1 & 4 \\
\hline Spring onion & $3.25 \mathrm{~kg}$ & 0.47 & 2 & 1 & 2,5 \\
\hline Beans & $1.5 \mathrm{~kg}$ & 0.16 & 2 & 1 & 1 \\
\hline Chilli & $4.5 \mathrm{~kg}$ & 0.64 & 3 & 1 & 3 \\
\hline Ginger & $2 \mathrm{~kg}$ & 0.29 & 1 & 1 & 4 \\
\hline Pumpkin & $1.25 \mathrm{~kg}$ & 0.18 & 1 & 1 & 2 \\
\hline Spinach & $3 \mathrm{~kg}$ & 0.43 & 5 & 1 & 1 \\
\hline Cabbage & $4 \mathrm{~kg}$ & 0.57 & 1 & 1 & 2 \\
\hline Potato & $3 \mathrm{~kg}$ & 0.43 & 2 & 1 & 3 \\
\hline Pakcoy & $4.5 \mathrm{~kg}$ & 0.64 & 4 & 1 & 1.5 \\
\hline Rggplant & $1,7 \mathrm{~kg}$ & 0.24 & 1 & 1 & 3 \\
\hline Tomatoes & $18 \mathrm{~kg}$ & 2.57 & 5 & 1 & 2 \\
\hline Carrot & $2.5 \mathrm{~kg}$ & 0.36 & 2 & 1 & 3 \\
\hline
\end{tabular}

Information:

(1) results of survey/preliminary research

(2) a. determination of total production per day to meet needs (1) study of plant species productivity reference and analysis of data from demonstration gardens b. Number of plants needed: total production per week/plant productivity (productive mass) per week.

(3) study of plant productive mass reference, number of harvests and/or duration of production (months), and data analysis from the pilot farm

Most of the food needs for the islands in Tatoareng District are met from the surrounding islands or depend on other areas which can affect the prices of vegetables and spices. This condition causes vulnerability to food supply, due to very limited transportation infrastructure constraints and weather factors which greatly affect the smooth distribution of food ingredients. The table above shows various vegetables and spices that are the daily consumption needs of the surrounding community. In the district of Tatoareng itself, the community must import vegetables from outside the island such as cabbage,

potatoes, beans, pumpkins and eggplants to meet their daily consumption needs. Each type of imported vegetables that are needed the most per week are $4 \mathrm{~kg}$ of cabbage, $3 \mathrm{~kg}$ of potatoes and $2.5 \mathrm{~kg}$ of carrots.

In Tatoareng District, for local vegetables, only kale is available as well as spices such as chili, shallots, garlic, scallions and ginger, because the average household in the vicinity has their own garden. Even so, the existing production cannot meet the demands of the surrounding community. Spices and vegetables with the highest demand per week are tomatoes with a demand of $18 \mathrm{~kg}$, onions $5 \mathrm{~kg}$, and chili and pakcoy $4.5 \mathrm{~kg}$

The characteristics of the islands in the Tatoareng subdistrict, Sangihe Regency, have various soil conditions, microclimate, and availability of ground/surface water. Some of the land is not used optimally, only coconut is planted with grass cover plants. One of the efforts that can be done is to increase the ability to provide food independently by utilizing and optimizing local food sources according to the potential of each region. The results in the field show that the $\mathrm{pH}$ of the soil in the Tatoareng District ranges from 5.0 to 6.5 which can be categorized as normal to low. To increase the recommended vegetable and spice plants that can be cultivated. 


\section{CONCLUSION}

One of the efforts that can be done is to increase the ability to provide food independently by utilizing and optimizing local food sources in accordance with the potential of each region. The results of the analysis present several choices of types of vegetables and spices, prospects for economic benefits and their suitability for microclimate conditions. The choice of types of vegetables and herbs that can be cultivated has been confirmed to the community. The categories of choice or priority for vegetables and spices are: the first priority is tomatoes, the second priority is mustard pakcoy, the third priority is chili. Therefore, it is recommended that cultivating priority vegetables and remap can somewhat meet the needs of the community

\section{REFERENCES}

[1] Shah K, Dulal H (2015) Household capacity to adapt to climate change and implications for food security in Trinidad and Tobago. Reg Environ Change. doi:10.1007/s10113-015-0830- 1

[2] Mercer J., Dominey-Howes D., Kelman I., and Lloyd K. 2007. The potential for combining indigenous and western knowledge in reducing vulnerability to environmental hazards in small island developing states. Environmental Hazards. 7: 245-256

[3] Komnitsas K.A. and Doula M.K. 2017. Framework to improve sustainability of agriculture in small islands: The case of Pistacia vera L. cultivation in Aegina, Greece. Environmental Forensics . Volume 18, Issue 3. https://doi.org/10.1080/15275922.2017.1340370

[4] Glaser M, Glaeser B (2014) Towards a framework for crossscale and multi-level analysis of coastal and marine socialecological systems dynamics. Reg Environ Change. doi:10.1007/s10113-014-0637-5

[5] Leunufna S. and Evans M. 2014. Ensuring food security in the small islands of Maluku: A community genebank approach. Journal of Marine and Island Cultures.vol 3, 125133

[6] Thornton, T. F., and Scheer A.M. 2012. Collaborative engagement of local and traditional knowledge and science in marine environments: a review. Ecology and Society 17(3): 8. http://dx.doi.org/10.5751/ES-04714-170308

[7] Daly, M.; Poutasi, N.; Nelson, F.; Kohlhase, J. 2010. Reducing the climate vulnerability of coastal communities in Samoa. J. Int. Dev., 22: 256-281.

[8] Corbett, J.; Rambaldi, G.; Kyem, P.; Weiner, D.; Olson, R.; Muchemi, J.; McCall, M.; Chambers, R. 2006. Mapping for Change: The Emergence of a New Practice. Participatory Learning and Action 54, 13-19

[9] Bohensky, E.L.; Butler, J.R.A.; Mitchell, D. 2011. Scenarios for knowledge integration: Exploring ecotourism futures in Milne Bay, Papua New Guinea. J. Marine Biology., doi:10.1155/2011/504651. 